\title{
Stimulating the increasing of natural soil fertility: economic and environmental aspects
}

\author{
Yasnolob I.O. ${ }^{1}$, Chayka T.O. ${ }^{1}$, Galych O.A. ${ }^{1}$, Kolodii O.S. ${ }^{1}$, Moroz S.E. ${ }^{1}$, \\ Protsiuk N.Yu. ${ }^{2}$, Lotych I.I. ${ }^{3}$ \\ 1Poltava State Agrarian Academy, Ukraine, 1-ka@ukr.net \\ ${ }^{2}$ Khmelnytska Humanitarian-Pedagogical Academy, Ukraine \\ ${ }^{3}$ Agro-Economic College of Poltava State Agrarian Academy, Ukraine \\ Sumbitted: Accepted:
}

\begin{abstract}
The necessity to increase soil fertility by identifying their critical condition, which is associated with developing erosion processes, increasing acidity and decreasing humus, has been proven in the article. The requirement of introducing crop rotations and their legal regulation in Ukraine has been determined. The practice connected with the questions of supporting soil quality and crop rotations in different countries, members of the EU has been presented. The assessment of modern farming systems (intensive, organic, no-till, strip-till, precise, bio-enzyme, biogenic) taking into account economic, ecological, technological-energy, and social factors aimed at determining their impact on the natural soil fertility has been conducted. The expediency of improving soil quality in terms of its evaluation has been revealed. The necessity of introducing economic incentives or penalties to landowners or land users for agro-ecological condition of farmlands basing on the methods of land money value has been substantiated.
\end{abstract}

Key words: farmlands; natural soil fertility; soil quality; crop rotation; farming systems; economic incentives; soil bonitet

\section{Introduction}

Land resources - the most valuable wealth of Ukraine - make $70 \%$ of its territory (33 million hectares or $80 \%$ is arable land) and require rational and efficient management, which determines the well-being of the present and future generations. However, convincing successes of scientific-technical progress (mostly material) stipulated the formation of the consumer nature of civilization, resulting in deepening soil degradation processes.

The problem of nutrients' balance in arable farming aggravated, soil acidity increases, the content of humus decreases. The negative balance of nutrients in soils was formed, dehumification spread, the area of medium and highly acidic soils significantly increased. Thus, as a result of the unprecedented development of erosion processes, the area of degraded soils increases annually by 90 thousand hectares; soil losses are 600 million tons, of water - 16 billion m3. Drying out and desertification of territories, soil mortification are connected with these processes. Almost every third hectare (30.7\%) is eroded and every second is dangerously deflationary, every fourth hectare is acid. On the completely, almost every second hectare (49.7 - 47.4\%) is acid in the areas of Forest-Steppe and Polissia.

The average annual losses of humus because of unbalanced introduction and removal of organic matter and erosion are more than $1.0 \mathrm{t} / \mathrm{ha}(1,228 \mathrm{~kg} / \mathrm{ha})$ of land under cultivation, the losses in terms of nitrogen equivalent are nearly 10.0 billion m3 of gas (Chayka, 2014).

The violation of ecologically admissible ratios of arable land, forage lands, forest and water territory areas, negatively affecting the stability of agrarian landscapes and the environment, takes place. Farmlands are also subject to contamination by industrial and domestic wastes, oil and oil products, pesticides and other chemicals, compressed by heavy tillage machinery, they are also flooded. The violation of crop rotations, the absence of effective control over observing the basic rules and regulations of land use, which lead to decreasing arable lands' productivity, take place (Chayka, Yasnolob, 2019). Land reform in agrarian sector requires new approaches to the regulation of land relations in order to use land resources more rationally and efficiently, which stipulates the development of the effective mechanism as to increasing the natural soil fertility.

Thus, the state of farmlands requires urgent measures to prevent and eliminate erosion processes, increase their deflationary stability, decrease acidity and restore humus (Kaminskyi, 2017). Their effectiveness depends primarily on the responsible attitude of landowners and land users, since the pursuit of super profits leads to destructive exploitation of farmlands 
(Nasarenko, 2016). As at present the mankind is just looking for the ways to overcome the consequences rather than preventing their manifestation, the introduction of economic mechanisms of incentives ((Borysova, 2003) to prevent the damaging impact of human activities on farm lands is now becoming urgent. The introduction of crop rotations and such farming systems, which would help restore and increase the natural soil fertility, is particularly topical.

The aim of the article is to study the reasons of deteriorating soil quality in Ukraine in order to determine agro-technological measures and economic methods for the conservation and restoration of their natural fertility.

\section{Results and discussion}

The current process of world agriculture specialization began a long time ago and it is steadily spreading in Ukraine. The system of fertility management is becoming more complicated, the requirements to soils are increasing together with the deepening of this process (the saturation of rotation systems with intensive crops, the introduction of new high yielding varieties and hybrids, the growth of the scales of using fertilizers, plant protection chemicals and power consuming cultivation technologies). They must ensure the sown areas with not only favorable air-water and nutrient regimes, but also have a significant phytosanitary function, the ability to prevent the formation of a high concentration of applied chemical compounds, etc. Manufacturers in pursuit of "quick" money concentrate their efforts on producing the maximal amount of highly profitable products. Therefore, today the problem of rational distributing intensive crops, such as sunflower, corn, rape, and soybeans, is extremely topical. Although "the optimization" of their distribution has not been sufficiently studied, in some parts of Ukraine there are considerable discrepancies between their production specialization and natural factors. In particular, the recultivation or continuous growing of corn and sunflower most widely spread at present leads to a considerable decrease of their yields and the increase of weeds, including specific species (Maliienko, 2010).

In case of continuous growing crops the decreasing of their yields and worsening the quality of harvest are observed, which is most often connected not only with increasing weed-infestation of crops and damaging them with pests and diseases, but also with the unilateral using soil nutrients and accumulating various toxic substances in the soil - products of plants' vital activity and microorganisms.

Scientific and technical progress and the growth of production-resource potential smooth the existing contradictions to some extent. Under the optimal provision with fertilizers and pesticides, the use of disease-resistant varieties, bio-preparations and other means of crop protection, the importance of crop rotation concerning mineral nutrition, weeds, pests and diseases' control is weakened, the possibility of crop re-cultivation increases (Kharchenko, Mishchenko, 2015).

Therefore, the primary task of agricultural producers is the development and introduction of crop rotations, because their obligatory condition is determined by the legislation and the following legal enactments: Land Code of Ukraine of 25.10 .2001 № 2768-III, Laws of Ukraine "On Amendments to Some Laws of Ukraine on the Preservation of Soil Fertility" of 04.06.2009 № 1443-VI, "About Land Regulation" of 22.05.2003 № 858-IV, “About Land Protection” of 19.06.2003 № 962-IV, Resolution of the Cabinet of Ministers of Ukraine about "The Order of Developing Land Regulation Projects, which Provide EnvironmentalEconomic Substantiation of Crop Rotation and Farmland Management" of 02.11.2011№ 1134.

However, only 3.8\% of agricultural enterprises have prepared crop rotation projects, and it shows the absence of their practical performance and the lack of interest among agricultural producers (owners and leaseholders) as to preserving and restoring soil fertility.

The experience of the European Union should be mentioned concerning the using of the system of subsidies for farmers who follow the compulsory requirements as to maintaining soils in proper condition: the principle of diversification (strict banning of monocultures); temporary limitations on growing the same crops in the same field. Thus, according to the data of Directorate General for Agriculture and Rural Development of the European Commission, the regulation aimed at maintaining soil quality and crop rotations in the countries-members of the EU takes place differently (Table 1). Overall, $100 \%$ of cultivated land in the European Union is used in crop rotations, and in the USA - 85\%.

Table 1. The peculiarities of the policy to maintain soil quality and crop rotations in the EU member countries (according to Nazarenko, 2016)

\begin{tabular}{|c|c|}
\hline Country & The content of policy \\
\hline Bulgaria & Flax, sunflower, and sugar beet cultivating is prohibited in the same field for two years \\
\hline Romania & It is not allowed to grow sunflower in the same fields over 2 years \\
\hline Hungary & $\begin{array}{l}\text { It is not allowed to grow sunflower, wheat, triticale and barley on the same land for more than } 2 \text { years. } \\
\text { It is allowed to cultivate corn in the same fields no longer than three years }\end{array}$ \\
\hline Finland & Agricultural producers must cultivate at least two crops \\
\hline France & $\begin{array}{l}\text { Farmers are allowed to grow at least three crops, it is necessary to allocate at least } 5 \% \text { of the land } \\
\text { area under each of them }\end{array}$ \\
\hline Germany & $\begin{array}{l}\text { Farmers are allowed to cultivate at least three crops, it is necessary to allocate at least } 15 \% \text { of land } \\
\text { area under each of them }\end{array}$ \\
\hline Greece & At least $20 \%$ of the land in crop rotations has to be allocated under legumes \\
\hline
\end{tabular}


Other countries, which are not mentioned above and have no detailed rotations, adopted their own rules of soil quality control. The supervisory bodies there conduct the selective control. This system is standardized and can be used in Ukraine (Yasnolob, Chayka, 2018).

The analysis of the results of numerous researches shows the use of introducing crop rotations. Thus, 1.0-1.4 $t /$ ha of winter wheat yield increase and more than $1.0 \mathrm{t} / \mathrm{ha}$ of corn are related with the share of introduced crop rotation. Besides, it was proved that only after introduced crop rotation moisture is used most effectively, the system of fertilization, soil tillage, and protection from pests and diseases are manifested most effectively. Weed infestation is reduced by 5 times in the developed crop rotation. Such crop rotation is the key factor of moisture conservation and biologization of farm products (Chayka, 2013). In order to preserve and increase natural soil fertility, it is necessary to use farming systems not only with the aim of increasing crop yields, but taking into account environmental, technological-energy and social components (Chayka, Yasnolob, 2018).

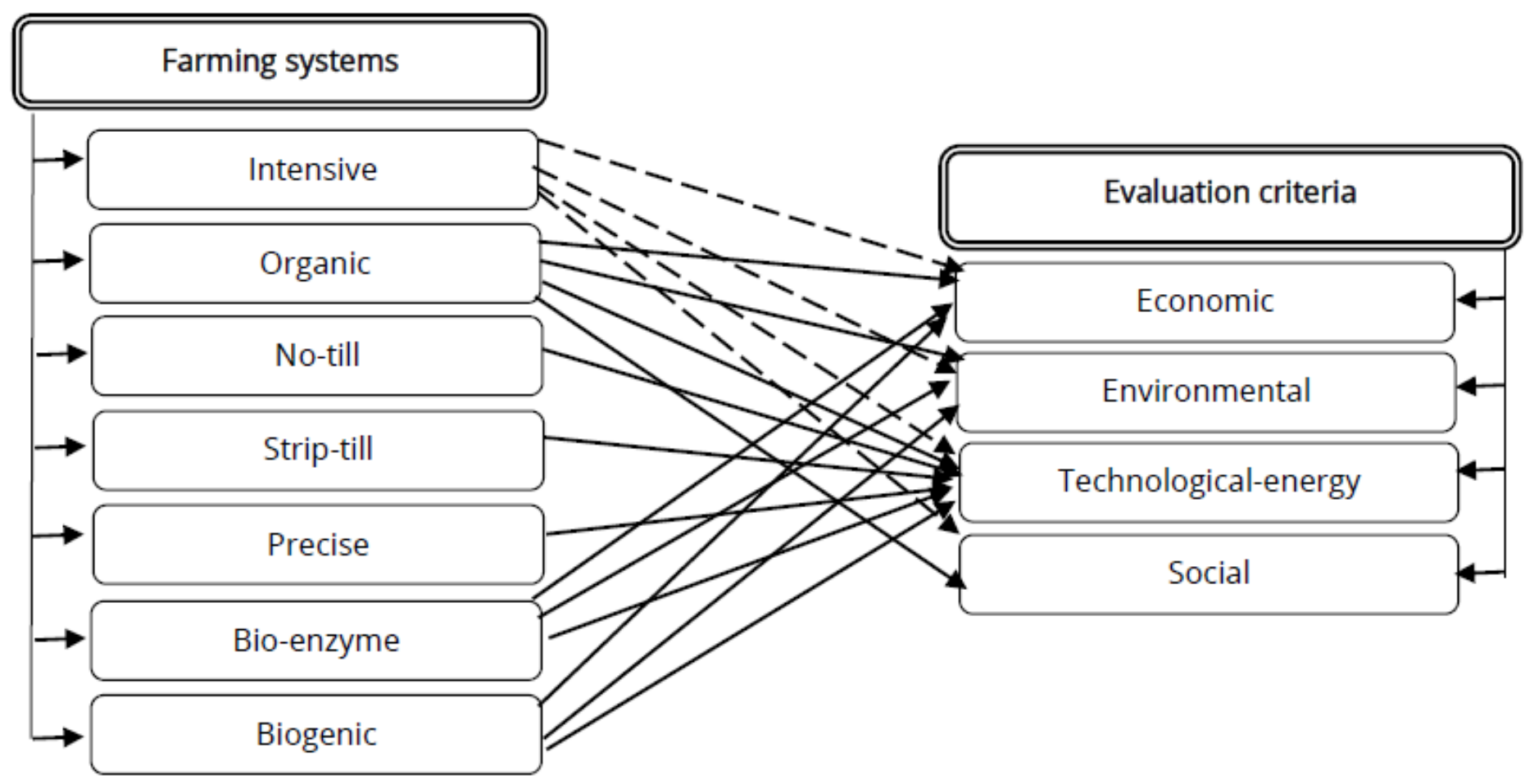

Fig. 1. The evaluation of the impact of farming systems. $\rightarrow$ the most positive impact, $\quad$ - the most negative impact, --------neutrality.

Thus, according to the conducted estimation, it is possible to make the conclusion that under the present conditions, the most favorable is organic farming system, which takes into account natural processes and does not harm the external environment, but, on the contrary, it assists its restoration. Organic farming system becomes most effective in case of maintaining associated crops, crop rotations and minimum soil tillage (Yasnolob, Pysarenko, Chayka, 2018).

It is also worth noting that natural soil fertility is the object of evaluation, as a logical continuation of the complex land survey and precedes its economic assessment. The main aim of evaluation is to determine the relative quality of soils according to their fertility, that is, determining how much one soil is worse or better than the other as to its natural and steadily acquired properties. Thus, soil fertility is the main qualitative characteristics, which satisfies plant growing, providing essential nutrients and conditions.

Soil bonitet (B) is a quantitative assessment of its natural fertility and is expressed in bonitet scores (b $\leq 100$ scores). As a rule, there is no doubt that its specific agrochemical indices and thus the specific bonitet score characterize each field. At present, there are different approaches to soil evaluation according to crop yield (Agro-Economic, 2014):

1. Total bonitet according to crop yields.

2. Agrochemical bonitet.

3. Environmental-agrochemical bonitet.

In general, it can be stated that the corresponding rate of bonitet score price (PS) corresponds to each approach of bonitet assessment. Now environmental- agrochemical bonitet score is recommended (Ecologica, 2010); (Yeshchenko, Kopytko, 2013), which includes in a number of environmental criteria (agro-climatic conditions, salinity, acidity, swampiness, contamination with radionuclides heavy metals, pesticide residues) and agrochemical indices.

We agree with the opinion of V.A. Borisova that in order to preserve and increase the natural soil fertility it is necessary to use economic incentives, based on the methods of farmland money evaluation (Borysova, 2003). The motive of economic incentives of landowners and land users is increasing the score of agro-ecological land evaluation, which is determined during regular agro-chemical examination. The necessary condition of stimulation is the increasing of all agro-chemical indices of soil fertility (Table 2). 
Table 2. The rate of economic incentives for increasing agro-ecological farmland evaluation (here and in Table 3 - according to Borysova, 2003)

\begin{tabular}{cccc}
\hline $\begin{array}{c}\text { Increasing the rate of } \\
\text { agro-ecological land } \\
\text { evaluation, scores }\end{array}$ & $\begin{array}{c}\text { The rate of economic } \\
\text { incentives referring to } \\
\text { land money evaluation, } \%\end{array}$ & $\begin{array}{c}\text { Increasing the rate of } \\
\text { agro-ecological land } \\
\text { evaluation, scores }\end{array}$ & $\begin{array}{c}\text { The rate of economic } \\
\text { incentive referring to land } \\
\text { money evaluation, } \%\end{array}$ \\
$0.1-1.0$ & 0.5 & $10.1-11.0$ & 5.5 \\
$1.1-2.0$ & 1.0 & $11.1-12.0$ & 6.0 \\
$2.1-3.0$ & 1.5 & $12.1-13.0$ & 6.5 \\
$3.1-4.0$ & 2.0 & $13.1-14.0$ & 7.0 \\
$4.1-5.0$ & 2.5 & $14.1-15.0$ & 7.5 \\
$5.1-6.0$ & 3.0 & $15.1-16.0$ & 8.0 \\
$6.1-7.0$ & 3.5 & $16.1-17.0$ & 8.5 \\
$7.1-8.0$ & 4.0 & $17.1-18.0$ & 9.0 \\
$8.1-9.0$ & 4.5 & $18.1-19.0$ & 9.5 \\
$9.1-10.0$ & 5.0 & $19.1-20.0$ & 10.0 \\
\hline
\end{tabular}

The levers of economic influence on the efficiency of land use are ecological- agrochemical land evaluation in scores; the rate of punitive penalties for the deterioration of the land ecological state (see Table 3). Thus, if the activity of landowner or land user resulted in deteriorating agro-ecological condition of the soil, he (she) must respond appropriately to restore its fertility and pay punitive penalties provided by the law. In our opinion, it will increase the responsibility of landowner or land user in further economic activity.

Table 3. The rate of punitive penalties for decreasing agro-ecological farmland evaluation

\begin{tabular}{cccc}
\hline $\begin{array}{c}\text { Decreasing the rate of } \\
\text { agro-ecological land } \\
\text { evaluation, scores }\end{array}$ & $\begin{array}{c}\text { The rate of punitive penalties } \\
\text { referring to land money } \\
\text { evaluation, } \%\end{array}$ & $\begin{array}{c}\text { Decreasing the rate of } \\
\text { agro-ecological land } \\
\text { evaluation, scores }\end{array}$ & $\begin{array}{c}\text { The rate of punitive } \\
\text { penalties referring to } \\
\text { land money } \\
\text { evaluation, }\end{array}$ \\
0.1-1.0 & 1.0 & $10.1-11.0$ & 11.0 \\
$1.1-2.0$ & 2.0 & $11.1-12.0$ & 12.0 \\
$2.1-3.0$ & 3.0 & $12.1-13.0$ & 13.0 \\
$3.1-4.0$ & 4.0 & $13.1-14.0$ & 14.0 \\
$4.1-5.0$ & 5.0 & $14.1-15.0$ & 15.0 \\
$5.1-6.0$ & 6.0 & $15.1-16.0$ & 16.0 \\
$6.1-7.0$ & 7.0 & $16.1-17.0$ & 17.0 \\
$7.1-8.0$ & 8.0 & $17.1-18.0$ & 18.0 \\
$8.1-9.0$ & 9.0 & $18.1-19.0$ & 19.0 \\
$9.1-10.0$ & 10.0 & $19.1-20.0$ & 20.0 \\
\hline
\end{tabular}

If in the course of the regular agrochemical soil survey it was found that the rate of its agro-ecological score did not change, the incentives are inexpedient. First, it is worth stimulating expanded reproduction of the natural soil fertility, as it motivates land owners and land users to invest additional capital (financial, intellectual, innovation, etc.) in the protection and restoration of soil fertility.

Economic incentives should not exceed the amount of punitive penalties in case of changing agro-ecological assessment to increasing or decreasing. The presented variant of the economic mechanism of the rational land resources' using and protecting will contribute to the economic interest of landowners and land users in increasing natural fertility of farm lands and the rate of agro-ecological evaluation in scores.

\section{Conclusions}

Thus, there is a vital necessity in Ukraine to increase natural soil fertility based on introducing farming systems and crop rotations by landowners or land users based on domestic and foreign experience. Land resources and favorable climatic conditions stipulate a high potential of manufacturing necessary crops in Ukraine. The need arises to implement the effective economic mechanism of stimulating landowners and land users to improve the soil quality based land money evaluation, since the state of its natural fertility today solves the problem of food security of the present and future generations. 


\section{References}

Chayka, T.O. (2014). Causes and Mechanisms of Economic Incentives for Increasing Soil Fertility. Bulletin of Poltava State Agrarian Academy, 3, 155-158. Available from: https://www.pdaa.edu.ua/sites/default/files/visnyk/2014/03/34.pdf (in Ukrainian)

Agro-Economic and Environmental Bases of Forecasting and Programming the Level of Crops. (2014). O. V. Kharchenko Ed.). Sumy: Universytetska knyha (in Ukrainian)

Borysova, V.A. (2003). Economic Restoration of Natural Resource Potential of Agro-Industrial Complex. Thesis of Doctoral Dissertation. Mykolaiiv. Mykolaiiv State Agrarian University (in Ukrainian)

Chayka, T.O. (2013). The Development of Organic Products' Manufacturing in the Agrarian Sector of Ukraine's Economy: Monograph. Donetsk: Znanie (in Ukrainian)

Ecological Problems of Farming: textbook. (2010). V. P. Hudz (Ed.). Zhytomyr: Publishing house "Zhytomyr National AgroEcological University" (in Ukrainian)

Kaminskyi, V.F. (2018). Scientific Bases of Optimizing Modern Farming Systems under Climate Change. Available from: http://zemlerobstvo.com/?p=5163/ (in Ukrainian)

Kharchenko, O.V., Mishchenko, Yu.H, Masyk, I.M., Prasol, V.I., Davydenko, H.A. (2015). Agro-Economic and Ecological Assessment of Crop Rotation. Sumy: Mriia (in Ukrainian)

Maliienko, A.M. (2010). The System of Soil Cultivation and Protection against Weeds. Scientific bases of Agro-Industrial Production in the Forest-Steppe Zone. Kyiv: Ahrarna Nauka (in Ukrainian)

Nasarenko, M. (2018). Problem Crop Rotation. Available from: www.agroinvest.org.ua/ukr/?nid=news|2936\&ntype=agsector (in Ukrainian)

Yasnolob I.O., Chayka T.O., Galych O.A., Gorb O.O., Opara M.M., Opara N.M., Kaliuzhna Y.P., Mokiienko T.V. (2018). Prerequisites and peculiarities of conservation and restoration of ecosystem stability. Ukrainian Journal of Ecology, 8(3), 143-148. Available from: https://www.ujecology.com/articles/prerequisites-and-peculiarities-of-conservation-and-restoration-of-ecosystemstability-of-the-concept-of-sustainable-dev.pdf

Yasnolob, I., Chayka, T., Aranchiy, V., Gorb, O., Dugar, T. (2018). Mycorrhiza as a biotic factor, influencing the ecosystem stability. Ukrainian Journal of Ecology, 8(1), 363-370. doi: http://dx.doi.org/10.15421/2018_223

Yasnolob, I.O., Chayka, T.O., Gorb, O.O., Kalashnyk, O.V., Konchakovskiy, Ye.A., Moroz, S.E., Shvedenko, P. Yu. (2019). Using Resource and Energy-Saving Technologies in Agricultural Production as a Direction of Raising Energy Efficiency of Rural Territories. Ukrainian Journal of Ecology, 9(1), 244-250. Available from: https://www.ujecology.com/articles/using-resource-andenergysaving-technologies-in-agricultural-production-as-a-direction-of-raising-energy-efficiency-of-r.pdf.

Yasnolob, I.O., Pysarenko, V.M., Chayka, T.O., Gorb, O.O., Pestsova-Svitalka, O.S., Kononenko, Zh.A., Pomaz, O.M. (2018). Ecologization of Tillage Methods with the Aim of Soil Fertility Improvement. Ukrainian Journal of Ecology, 8(2), 280-286. doi:http://dx.doi.org/10.15421/2018082.

Yeshchenko, V.O., Kopytko, P.H., Butylo, A.P., Opryshko, V.P. (2013). Arable Farming. Kyiv: Lazuryt-Poligraph (in Ukrainian)

\section{Citation:}

Yasnolob, I.O., Chayka, T.O., Galych, O.A., Kolodii, O.S., Moroz, S.E., Protsiuk, N.Yu., Lotych, I.I. (2019). Stimulating the increasing of natural soil fertility: economic and environmental aspects. Ukrainian Journal of Ecology, 9(3), 267-271.

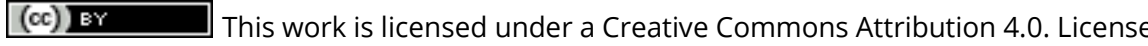

